\title{
A CONTRIBUTION TO THE WOOD ANATOMY OF THE CINCHONEAE, COPTOSAPELTEAE AND NAUCLEEAE (RUBIACEAE)
}

\author{
JIFKE KOEK-NOORMAN \\ Botanisch Museum en Herbarium, Utrecht
}

\section{SUMMARY}

Wood samples of a number of Cinchoneae and Naucleeae sensu Schumann were studied, and the results compared with data found in the literature. On the whole the representatives of the Cinchoneae appeared to show a rather high degree of similarity among each other with the exception, however, of the genera Coutarea, Exostemma, Corynanthe, Crossopteryx, and Hymenodictyon. The creation of the tribe Coptosapelteae and its inclusion in the Ixoroideae seem to be corroborated by the particular character of the wood anatomy. The restriction of the Naucleeae to Nauclea L. (Sarcocephalus Afzel.) is not supported by the anatomy of the wood.

\section{INTRODUCTION}

In two preceding papers (KOEK-NOORMAN 1969a, b) a survey of the wood anatomy of six subfamilies of the Rubiaceae, chiefly based upon a study of Suriname genera, was given. In connection with this survey the classifications of this family proposed respectively by SCHUMANN (1897), VERDCOURT (1958), and BREMEKAMP (1966) were discussed.

Coptosapelta and Crossopteryx, placed in the Cinchoneae by Schumann, are removed by Bremekamp because of the "ixoroid" pollination mechanism into a tribe of its own in the Ixoroideae. Verdcourt mentions the same pollination mechanism in Corynanthe and Hymenodictyon. However, he considers Coptosapelta to be the only genus which has to be removed because in opposition to Corynanthe, Crossopteryx, and Hymenodictyon it differs also in other characteristics from the Cinchoneae.

Hillia was placed by Bremekamp in a subfamily of its own. The wood structure proved to be in accordance with this view (KOEK-NOORMAN, 1969b).

The genera Bouvardia, Heterophyllaea, Hindsia, Manettia, Danais, Coursiana and Hymenopogon, also placed in the Cinchoneae by Schumann, were transferred to the Hedyotideae by Bremekamp. Verdcourt agreed with this opinion, and added to this group of genera another one, viz. Schismatoclada. In the present paper this group of genera is left out of account.

The Naucleeae are restricted by Bremekamp to Nauclea L. = Sarcocephalus Afzel. because of its connate ovaries; the genera Adina, Anthocephalus, Breonia. Mitragyna, Neonauclea and Uncaria all with free ovaries are referred by him to the Cinchoneae.

The purpose of the present investigation is to detect the similarities and 
WOOD ANATOMY OF SOME RUBIACEAE

differences in the structure of the wood of the genera concerned and to find out which classification agrees best with the results obtained in this field.

The main results of the anatomical investigations are listed in table 1.

\section{MATERIAL AND METHODS}

The methods are the same as those described in a preceding paper (KoEKNoORMAN 1969a). The material studied is listed at the end of the present paper.

\section{DISCUSSION}

\subsection{Discussion of the anatomical literature}

The descriptions and pictures given of the wood anatomy of various Rubiaceae in older publications and the results of my own study agree rather well.

GRAÇA DE FreITAS (1955) mentions the presence of libriform fibres and fibre tracheids in Sarcocephalus cordatus Miq. (= Nauclea subdita (Korth.) Merrill). In conformity with JANSSONIUS (1926) I observed fibre tracheids only. The descriptions and pictures of the wood of species of Adina, Anthocephalus, Calycophyllum, Corynanthe, Hymenodictyon, Mitragyna, Neonauclea and Nauclea (Sarcocephalus) as given by CHALK c.s. (1933), DADSwELl \& ECKERSLEY (1935), Den Berger (1926), Ferreinninha (1955), Fouarge c.s. (1935), Janssonius (1926), Kribs (1968), Normand (1960), Schmidt (1952), and TortoRELLI (1956), are in good agreement with each other and with the data collected during this investigation.

Schmidt reports the occurrence of many vessels in short radial multiples in the wood of Mitragyna ciliata Aubl. \& Pellegr. and of M.stipulosa O.Ktz., whereas other authors state: vessels (nearly) exclusively solitary, which agrees with my own results. Chalk c.s. found in different samples of Mitragyna stipulosa a varying proportion between the number of solitary vessels and the number of vessels arranged in radial multiples.

Janssonius' descriptions of Cinchona sp. does not agree with the anatomy of the Cinchoneae studied by me. He reports as many solitary vessels as vessels in radial multiples, the presence of fibre tracheids, and diffuse, reticulate, and paratracheal parenchyma. This combination of characters resembles the structure I found in representatives of the Naucleeae sensu Schumann (table I). In a preceding paper (1969b) I drew the attention to the possibility that Janssonius' material, as he himself admitted, was not correctly identified. However, SOLEREDER (1885) too states the presence of bordered pits in the fibre tissue of representatives of the Naucleeae as well as of the Cinchoneae (Cascarilla magnifolia and Cinchona calysaya). However, fibres with bordered pits did not occur in the material of the Cinchona species nor in that of other Cinchoneae sensu Schumann studied by me. If the findings of Janssonius and of Solereder with regard to the presence of bordered pits in the wood fibres of some Cinchona species should prove to be correct, that would mean that the taxonomic value of this character is not so important as has been assumed. 
The results of this investigation fit very well into the general picture of the wood anatomy of the family Rubiaceae given by MetCALFE \& CHALK (1950). Small differences like the presence or absence of crystals are perhaps due to intraspecific variations or to the fact that different species were studied. Metcalfe \& Chalk, to give another example, report rays wider than 4 cells in Calycophyllum and Nauclea, whereas in the material investigated by me most rays proved to be biseriate.

3.2. Discussion of the more recent tax on omic classifications in the light of the similarities and differences in the wood anatomy In "A contribution to the wood anatomy of South American Rubiaceae I" I argued that the definition of fibre tracheids and libriform fibres given by Moll and Janssonius is preferable because in this way a point is found which does justice to the classifications of the Rubiaceae elaborated by respectively Verdcourt and Bremekamp; the division based upon the presence or absence of bordered pits in the fibre tissue is in this respect of no value. For this reason the terms "fibre tracheid" and "libriform fibre" are used here in the sense given to them by Moll \& JANSSONIUS (1906; KOEK-NOORMAN 1969a).

Libriform fibres in the sense of Moll and Janssonius were found by me in species of Alseis, Calycophyllum, Capirona, Cinchona, Coutarea, Ferdinandusa, and Macrocnemum (table 1). In this group of genera there is in the vessels a slight tendency for an arrangement in radial multiples (mostly more than half of them), for four- to multiseriate rays, and for the suppression of the parenchyma or its reduction to a few cells. (An exception is found in Coutarea which has uni- and biseriate bands of parenchyma.) Schumann, Verdcourt and Bremekamp left these genera in the Cinchoneae. However, in a verbal communication Bremekamp stated that Coutarea occupies a rather isolated position, and that its inclusion in the Cinchoneae is doubtful, and that Exostemma too should be studied more intensively in its morphologic character before its position can be determined. E.caribaeum has fibre tracheids, solitary vessels, and small rays, and resembles more or less the remaining genera studied by me. Of these genera Adina, Anthocephalus, Mitragyna, Nauclea (Sarcocephalus), Neonauclea and Uncaria belong to the Naucleeae sensu Schumann. The wood samples investigated by me show a great similarity: they resemble each other not only in the presence of fibre tracheids, but also in the reticulate and diffuse parenchyma, in the high percentage of solitary vessels which generally are rather wide, and in the rays which are less than four cells wide. (An exception is found in Mitragyna rotundifolia, where a few 5-seriate rays are present.) In the wood anatomy therefore no argument can be found for restricting the Naucleeae to Nauclea (Sarcocephalus), and for removing the other genera to the Cinchoneae, from which they differ in this respect rather distinctly. This conclusion agrees with the conception of Verdcourt.

Cephalanthus is included in the Naucleeae by Schumann, but according to Bremekamp it occupies a very isolated position and does not belong to the Naucleeae because of the uni-ovular ovary cells and the very narrow wings of the 

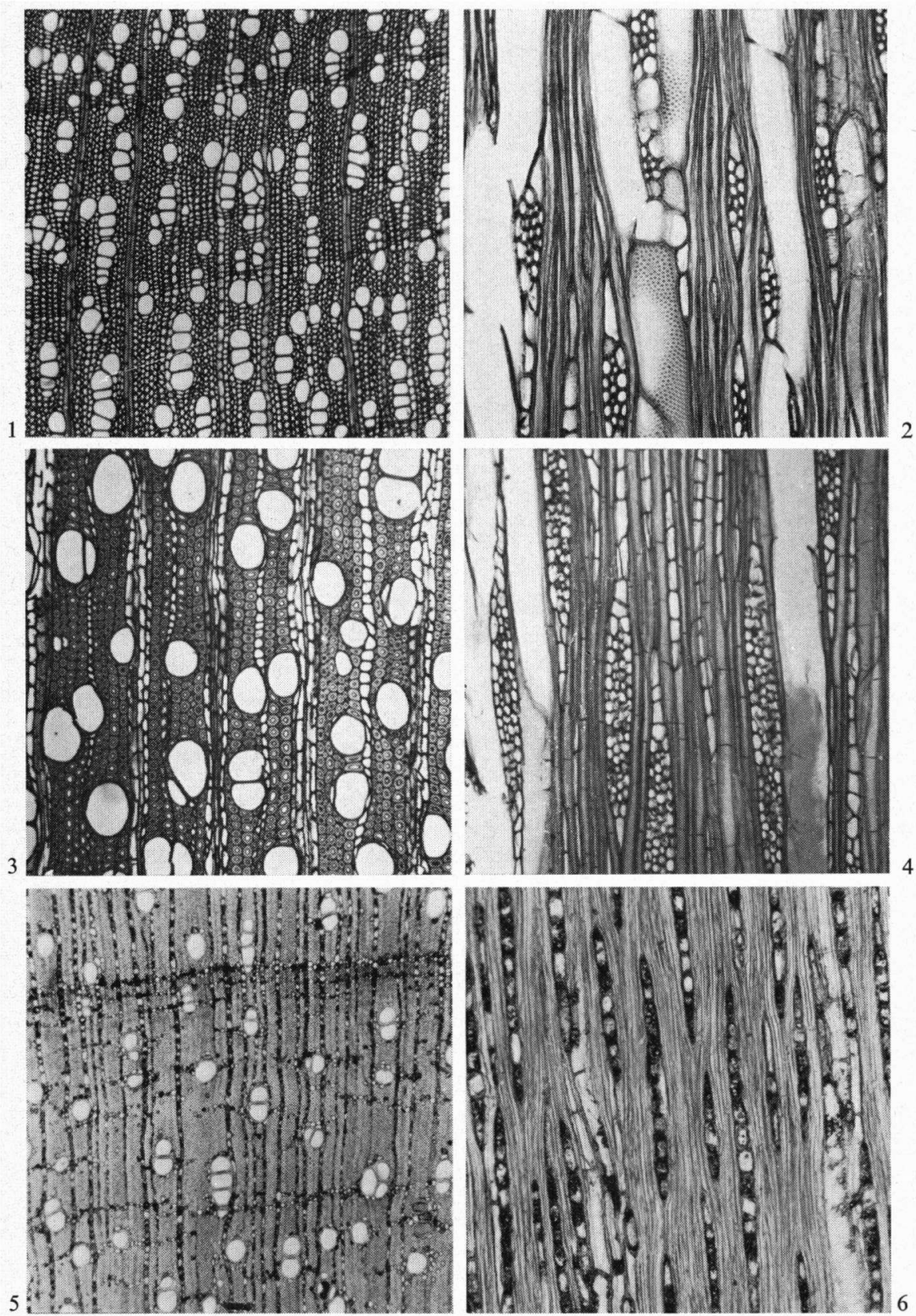

Plate I. fig. 1. Alseis floribunda Schott (Uw 6340) transv. sect. $45 \times$; fig. 2. Alseis floribunda Schott (Uw 6340) tang. sect. $115 \times$; fig. 3. Capirona surinamensis Brem. (Uw 172) transv. sect. $45 \times$; fig. 4. Capirona surinamensis Brem. (Uw 172) tang. sect. $45 \times$; fig. 5. Coutarea hexandra (Jacq.) K. Schum. (Uw 6334) transv, sect. $45 \times$; fig. 6 . Coutarea hexandra (Jacq.) K. Schum. (Uw 6334) tang. sect. $115 \times$. 
seed. The species studied by me possess fibre tracheids, but though they resemble the true Naucleeae in this point, they differ from them in the presence of ringporous vessels, in the uniseriate rays composed of almost exclusively upright and square cells and in the large proportion of vessels arranged in radial multiples.

Other genera with fibre tracheids are Corynanthe, Crossopteryx and Hymenodictyon. As mentioned in the introduction Schumann placed these genera in the Cinchoneae. Bremekamp removed Crossopteryx together with Coptosapelta to the Ixoroideae. (It is to be regretted that no wood sample of Coptosapelta was available and that in the literature no references with regard to the wood anatomy of this genus were found by me.) Verdcourt argues that the two genera Corynanthe and Hymenodictyon, which differ from the two other ones in the aestivation of the corolla, also should have been placed in this tribe by Bremekamp, but that Coptosapelta is the only genus which should be removed from the Cinchoneae, as it deviates also in several other points. Wood-anatomically the two genera Corynanthe and Crossopteryx appear to agree very well. They differ from the other Cinchoneae studied by me in several points and resemble the Naucleeae not only in the presence of fibre tracheids but also in the predominantly solitary vessels and the diffuse parenchyma. Hymenodictyon resembles Corynanthe and Crossopteryx not only in the presence of fibre tracheids but also in the structure of the rays and in the presence of apotracheal parenchyma, but in this genus more than half of the vessels are arranged in radial multiples, and the vessel diameter exceeds $100 \mu$.

Summarising we may say that the genera of the Naucleeae sensu Schumann show in their wood anatomy a great similarity with the exception, however, of Cephalanthus. Corynanthe, Crossopteryx and Hymenodictyon have much in common and resemble the Naucleeae in many respects, whereas they differ distinctly from the Cinchoneae. With the exception of Exostemma and Coutarea the Cinchoneae studied by me form a rather homogeneous group.

Anticipating on a subsequent paper dealing with the Cinchonoideae and Ixoroideae I can say that nearly all Ixoroideae which have been studied till now possess fibre tracheids. In many species the vessels are (almost) exclusively solitary, the parenchyma varies from scanty to rather abundant, and is mostly apotracheal, and uni- and/or biseriate rays are rather frequent.* The Naucleeae have a similar structure, and this applies also to Corynanthe and Crossopteryx. Exostemma shows some resemblance with the Naucleeae and Ixoroideae. In the Cinchonoideae much less correlation appears to exist between the subdivision in tribes and the wood anatomical characters: on the one hand we find a group of genera with libriform fibres, many radial vessel multiples, rays wider than

* In my second paper on the wood anatomy of the Rubiaceae (1969b) I wrongly assumed that Chomelia tenuifora Bth. was a species of Chomelia L. (= Tarenna Gaertn.) and that it belonged therefore to the Ixoreae. However, Chomelia tenuiflora is a species of Chomelia Gaertn. = Anisomeris Presl., a genus listed in the Guettardoideae. The wood anatomy completely agrees with this position. I am much obliged to Prof. Dr. C. E. B. Bremekamp, who drew my attention to this error. 
WOOD ANATOMY OF SOME RUBIACEAE
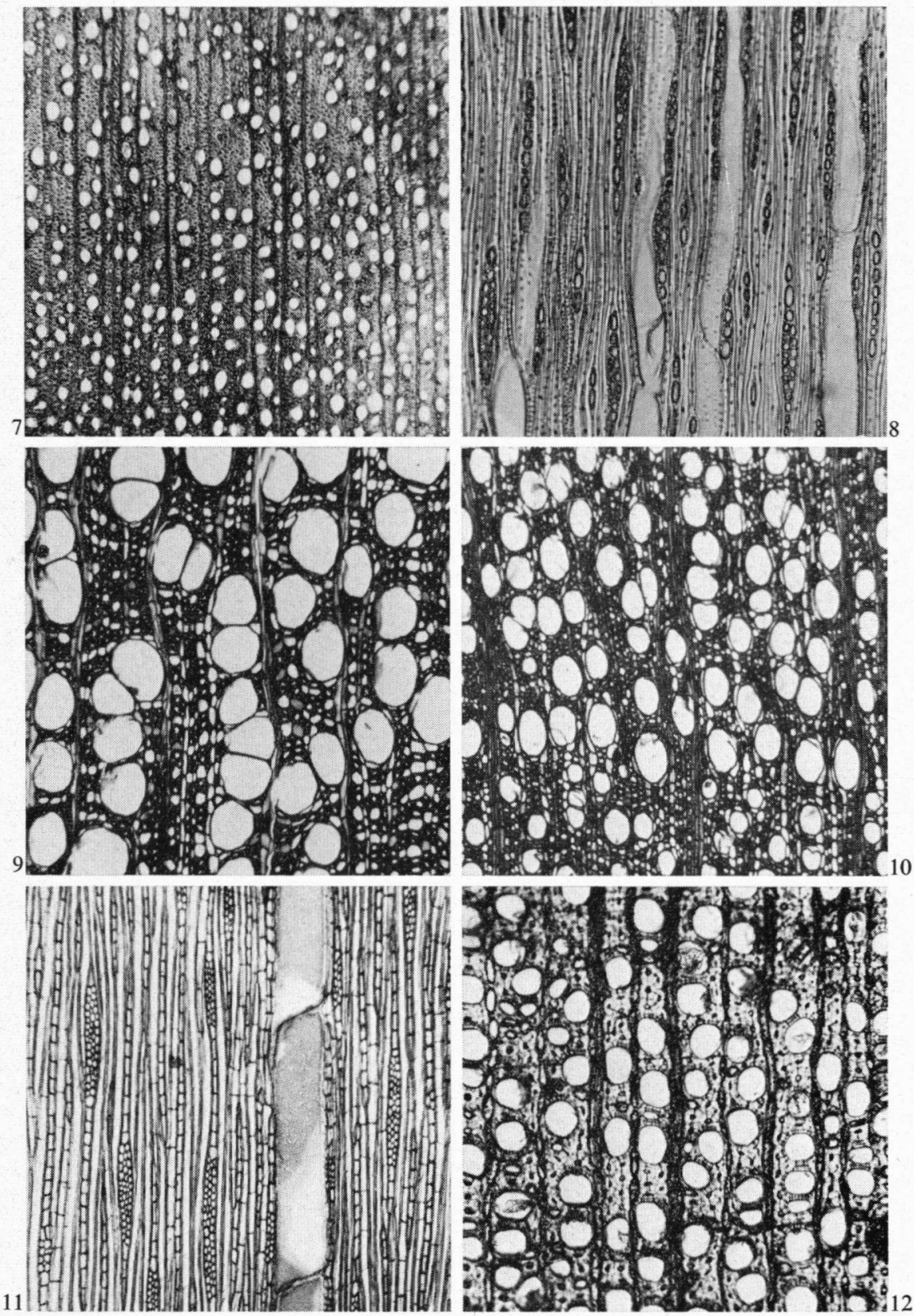

Plate II. fig. 7. Exostemma caribaeum (Jacq.) Roem. \& Schult. (Uw 2914) transv, sect. $45 \times$; fig. 8. Exostemma caribaeum (Jacq.) Roem. \& Schult. (Uw 2914) tang. sect. $115 \times$; fig. 9. Mitragyna macrophylla Hiern. (Uw 14957) transv. sect. $45 \times$; fig. 10. Mitragyna rotundifolia Ktz. (Uw 14945) transv. sect. $45 \times$; fig. 11. Anthocephalus cadamba (Roxb.) Miq. (Uw 10695) tang. sect. $45 \times$; fig. 12. Corynanthe paniculata Welw. (Uw 14959) transv. sect. $110 \times$. 
JIFKE KOEK-NOORMAN

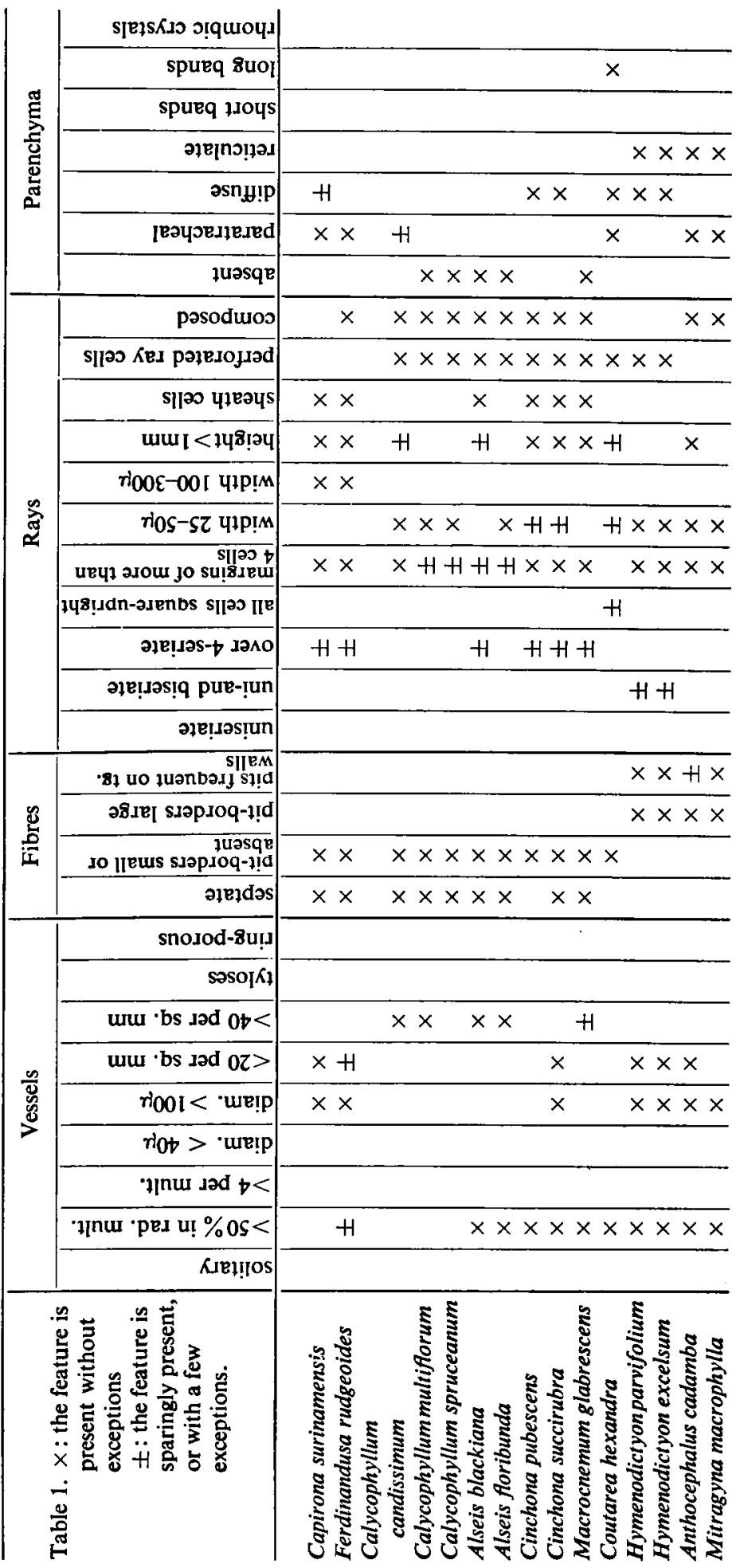


4 cells and a suppression or strong reduction of the parenchyma, on the other hand a group with fibre tracheids, many solitary vessels, narrower rays and better developed, predominantly apotracheal parenchyma. Particularly in the Rondeletieae and Condamineae both types of wood structure seem to occur side by side. In a subsequent study the author hopes to deal with this problem.

\section{ACKNOWLEDGEMENT}

The author is much indebted to Prof. Dr. C. E. B. Bremekamp for his correcting of the English text, to Mrs. M. Renaud-Maten and Mr. H. W. Miller for the preparation of the sections, and to Messrs. A. Kuiper and T. Schipper for their assistance with the illustrations. Furthermore I wish to thank the Curators of the wood collections at Amsterdam (Royal Trop. Inst.), Florence (Inst. Bot. Univ.), Lisbon (Lab. Hist. Tecn. Mad.), Nogent-sur-Marne, Princes Risborough, and Reinbek for providing me with valuable wood specimens.

\section{MATERIAL STUDIED}

Adina cordifolia Hook. f.: Siam - Uw 14936 (RTIw TP 371-1); Kambodja-Uw 14937 (RTIw TP 2183-21); India - Uw 15273 (FIw 529).

Adina fagifolia Val.: Indonesia - Uw 14938 (RTIw Ind. 14442).

Adina microcephala Hiern.: Mosambique - Uw 14939 (RTIw TP 1626-52).

Adina minutiflora Val.: Indonesia - Uw 14940 (RTIw Ind. 14417).

Adina multifolia Hav.: New Guinea - Uw 14941 (RTIw TP 3692-1).

Adina polycephala Bth.: Indonesia - Uw 14942 (RTIw Ind. 8814).

Adina rubrostipulata K. Schum.: East Africa - Uw 14943 (RTIw TP 4374-72); Uw 15561 (RBHw 1644).

Alseis blackiana Hemsl.: Panama - Uw 7193 (USw 776).

Alseis floribunda Schott.: Brazil - Uw 6340 (Reitz 1444, Santa Catarina; tree, 5 m high, diam. $4.5 \mathrm{~cm}$ ).

Anthocephalus cadamba (Roxb.) Miq.: Philippines - Uw 10694 (PRFw 134, Laguna); Uw 10747 (PRFw 488, Laguna).

Breonia spec.: Madagascar - Uw 15472 (CTFw 17051).

Calycophyllum candissimum (Vahl) DC.: Panama - Uw 11088 (USw 16555).

Calycophyllum multiflorum Griseb.: Argentine - Uw 7368 (USw W-4187).

Calycophyllum spruceanum Benth.: Argentine - Uw 7111 (USw 463); Brazil - Uw 10526 (W. Rodrigues \& F. Mello X 912, Manaus).

Capirona surinamensis Brem.: Suriname - Uw 172 (Stahel 172, Zanderij I); Uw 2426 (Lindeman 3681, Mapane Kreek area; tree, $15 \mathrm{~m}$ high, diam. $7.5 \mathrm{~cm}$ ); Uw 6861 (Schulz 8583, Suriname R., Jodensavanne; tree, $30 \mathrm{~m}$ high, diam. $45 \mathrm{~cm}$ ).

Cephalanthus occidentalis L: Indiana - Uw 10158 (USw 19616); Uw 9986 (Barghoorn 9202).

Cephalanthus salicifolius Humb. \& Bonpl.: Mexico - Uw 8527 (USw 13993).

Cinchona pubescens Vahl: Equador - Uw 10166 (USw 19654); Venezuela - Uw 12213 (Breteler 4616; treelet, about $6 \mathrm{~m}$ high).

Cinchona succirubra Pav.: Equador - Uw 7356 (USw 4089).

Corynanthe brachythyrsos K. Schum.: Cameroun - Uw 14964 (RBHw 8155).

Corynanthe macroceras K. Schum.: Cameroun - Uw 14963 (RBHw 7503).

Corynanthe pachyceras K. Schum.: Cameroun - Uw 9499 (Breteler 2388).

Corynanthe paniculata Welw.: Angola - Uw 14959 (LISJw G155); Uw 14962 (RBHw 10664 = LISJw G132); Congo - Uw 14961 (RBHw 12017); Uw 15474 (CTFw 12767).

Coutarea hexandra (Jacq.) K. Schum.: Brazil - Uw 6334 (Reitz 14410, Santa Catarina; tree, $6 \mathrm{~m}$ high, diam. $3 \mathrm{~cm}$ ).

Crossopteryx africana K. Schum.: Tanganyika - Uw 14960 (RBHw 1887; Schlieben 499, diam. $6 \mathrm{~cm}$ ). 
Exostemma caribaeum (Jacq.) Roem.: Florida - Uw 2914 (Yw 49402); Uw 6270 (Yw 51255); Uw 6293 (Yw 51292); Puerto Rico - Uw 8386 (USw 6080).

Ferdinandusa rudgeoides (Bth.) Wedd.: Suriname - Uw 1903 (Lanjouw \& Lindeman 2757, Nassau Mountains; tree, $4 \mathrm{~m}$ high, diam. $3 \mathrm{~cm}$ ); Uw 1933 (Lanjouw \& Lindeman 2807, Nassau Mountains; tree, diam. $15 \mathrm{~cm}$ ); Uw 2551 (Yw 44284, Maguire 24879, Saramacca R.; tree, $20 \mathrm{~m}$ high, diam. $30 \mathrm{~cm}$ ); Uw 5449 (Schulz 7990; diam. $10 \mathrm{~cm}$ ).

Hymenodictyon excelsum Wall.: Indonesia - Uw 14948 (RTIw Ind. 26536); India - Uw 15284 (FIw 1024); Uw 15267 (PRFw 6123); Malaya - Uw 16268 (PRFw 7180).

Hymenodictyon parvifolium Oliv.: Africa - Uw 15625 (RBHw 11057).

Macrocnemum glabrescens (Bth.) Wedd.: Panama - UW 7052 (US Nat. Herb. 716459).

Mitragyna ciliata Aubr. \& Pellegr.: Nigeria - Uw 14944 (RTIw TP 1132-7).

Mitragyna macrophylla Hiern: Spanish Guinea - Uw 14957 (RTIw TP 1165-15).

Mitragyna rotundifolia O. Kuntze: Indonesia - Uw 14945 (RTIw Ind. 8258).

Mitragyna speciosa Korth.: Indonesia - Uw 14946 (RTIw Ind. 12827).

Mitragyna stipulosa O. Kuntze: West-Africa - Uw 6444 (RBHw 30).

Nauclea diderichii (Wildem.) Merr.: Irian - Uw 14956 (RTIw PT 4294-11); West-Africa Uw 6573 (Leeuwenberg 2787, Ivory Coast, $56 \mathrm{~km} \mathrm{~N}$. of Sassandra; tree, $35 \mathrm{~m}$ high).

Nauclea mitragyna (Miq.) Merr.: Irian - Uw 14952 (RTIw NNG 563); Uw 14953 (RTIw NNG 1311).

Nauclea orientalis L.: Irian - Uw 14954 (RTIw NNG 2116); India - Uw 15272 (FIw 510).

Nauclea subdita (Korth.) Merr.: Irian - Uw 14955 (RTIw NNG 1740).

Nauclea trillesii (Pierre) Merr.: Spanish Guinea - Uw 15463 (MADRw 1413).

Neonauclea bernardoi (Merr.) Merr.: Phillipines - Uw 10791 (PRFw 631).

Uncaria africana G. Don: Cameroun - Uw 9464 (Breteler 2136; diam. $3 \mathrm{~cm}$ ).

Uncaria guianensis (Aubl.) Gmel.: Suriname - Uw 2550 (Yw 44063); Uw 3834 (Lindeman 5543, Coppename R.; liana, diam. $2 \mathrm{~cm}$ ); Uw 6847 (Schulz 8454, Suriname R., Jodensavanne; liana, diam. $2.5 \mathrm{~cm}$ ).

\section{REFERENCES}

BREMEKAMP, C. E. B. (1952): The African species of Oldenlandia L. sensu Hiern. et K. Schum. Verh. Kon. Ned. Ak. 2e ser. 48: (2): 27-28.

- (1954): Les sous-familles et les tribus des Rubiacéés. Rapp. et Comm. 8e Congr. Int. Bot., Paris, sect. 2, 4, 5, et 6: 113-114.

- (1966): Remarks on the position, the delimitation and the subdivision of the Rubiaceae. Act. Bot. Neerl. 15 : 1-33.

Chalk, L., J. Burtt Davy, H. E. Desch \& A. C. Hoyle (1933): Twenty West African Timber Trees. Oxford.

Chattaway, M. M. (1933): Ray development in the Sterculiaceae. Forestry 8: 93-108.

DADSWELL, H. E. \& A. M. EcKERSLEY (1935): The identification of the principal Commercial Australian Timbers other than Eucalypts. Melbourne.

Den Berger, L. G. (1926): Houtsoorten der Cultuurgebieden van Java en van Sumatra's Oostkust. Med. Proefst. Boschw. 13.

Ferreirinha, M. P. (1955) Catálogo das Madeiras de Moçambique. I. Mem. Ser. Bot. 2.

Fouarge, J., G. Gérard \& E. Sacré (1953): Bois du Congo. Brussels.

Graça de Freitas, M. C. P. (1955): Estudo das Madeiras de Timor. Mem. Ser. Bot. 3: 39-41.

International Association of Wood Anatomists (1964): Multilingual glossary of terms used in wood anatomy. Winterthur.

JANssonius, H. H. (1940): Anatomische Bestimmungstabellen für die Javanischen Hölzer. Leiden.

Koek-Noorman, J. (1969a): A contribution to the Wood Anatomy of South American (chiefly Suriname) Rubiaceae. I. Act. Bot. Neerl. 18: 108-123.

- (1969b): A contribution to the Wood Anatomy of South American (chiefly Suriname) Rubiaceae. II. Act. Bot. Neerl. 18: 316-334. 
KriBs, D. A. (1968): Commercial Foreign Woods on the American Market. New York.

Lebace, L. \& P. Staner (1964): Anatomie comparée des Bois d'Amérique latine et d'Afrique centrale. Tervuren.

Metcalfe, C. R. \& L. Chalk (1950): Anatomy of the Dicotyledons. Oxford.

Moll, J. W. in Moll, J. W. \& H. H. Janssonius (1906): Micrographie des Holzes der auf Java vorkommenden Baumarten. I. Leiden.

MolL, J. W. \& H. H. JANssonius (1926): Micrographie des Holzes der auf Java vorkommenden Baumarten. IV. Leiden.

NoRmand, D. (1960): Atlas des bois de la Côte d'lvoire. Nogent-sur-Marne.

ReCORD, S. J. \& R. W. Hess (1944): Timbers of the New World. New Haven.

REINDERS, E. (1935): Fiber-tracheids, libriform wood fibers and systematics in wood anatomy. Trop. Woods 44: 30-36.

- (1941): Handleiding bij de plantenanatomie. Wageningen.

SCHMIDT, E. (1951): Überseehölzer. Berlin.

Schuman, K. in Engler, A. \& K. Prantl (1897): Die natürlichen Pflanzenfamilien. IV (4). Leipzig.

SOLEREDER, H. (1885): Uber den systematischen Wert der Holzstruktur. München.

- (1898): Systematische Anatomie der Dicotyledonen. Stuttgart.

- (1908): Systematische Anatomie der Dicotyledonen. Ergänzungsband. Stuttgart.

Verdcourt, Ph. D. (1958): Remarks on the classification of the Rubiaceae. Bull. J. Bot. Brux. 28: 209-290. 